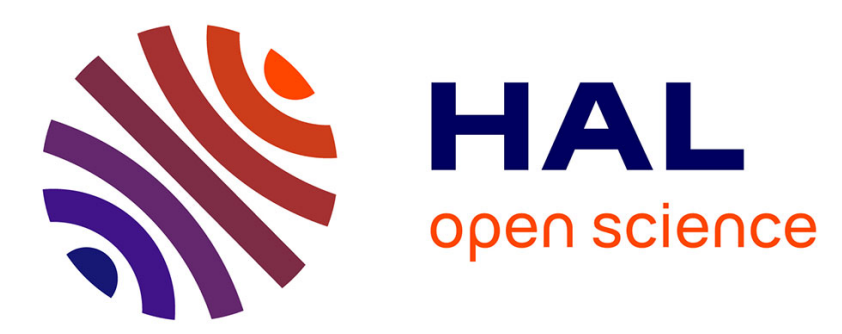

\title{
Terms of Trade Shocks and the Current Account in Small Island Developing States
}

\author{
Amelia Santos-Paulino
}

\section{To cite this version:}

Amelia Santos-Paulino. Terms of Trade Shocks and the Current Account in Small Island Developing States. The Journal of Development Studies, 2010, 46 (05), pp.855-876. 10.1080/00220381003623830 . hal-00594795

\section{HAL Id: hal-00594795 \\ https://hal.science/hal-00594795}

Submitted on 21 May 2011

HAL is a multi-disciplinary open access archive for the deposit and dissemination of scientific research documents, whether they are published or not. The documents may come from teaching and research institutions in France or abroad, or from public or private research centers.
L'archive ouverte pluridisciplinaire HAL, est destinée au dépôt et à la diffusion de documents scientifiques de niveau recherche, publiés ou non, émanant des établissements d'enseignement et de recherche français ou étrangers, des laboratoires publics ou privés. 


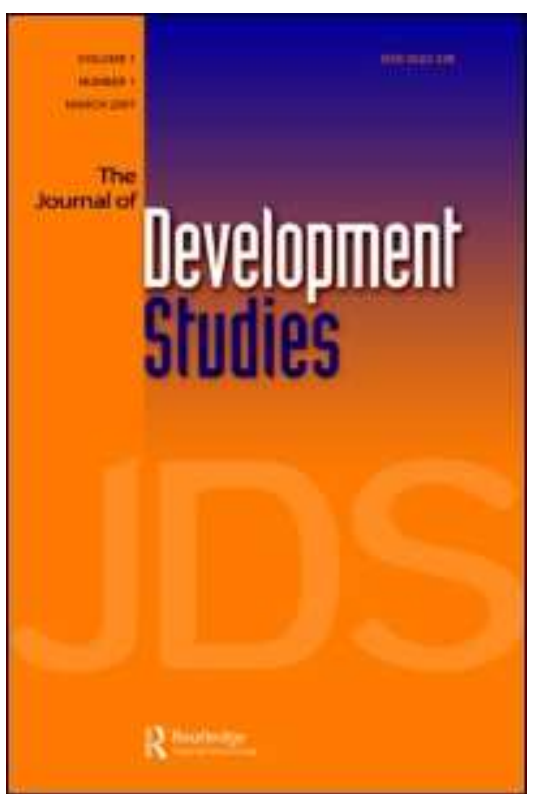

Terms of Trade Shocks and the Current Account in Small Island Developing States

\begin{tabular}{|r|l|}
\hline Journal: & Journal of Development Studies \\
\hline Manuscript ID: & FJDS-2009-Oct-0013.R1 \\
\hline Manuscript Type: & Papers in Special Issues \\
\hline Keywords: & $\begin{array}{l}\text { Diversification < Economics, Economic development }<\text { Economics, } \\
\text { Trade < Economics, Asia Pacific < Geographical Area, Caribbean }< \\
\text { Geographical Area, Vulnerability < Social Issues }\end{array}$ \\
\hline \multicolumn{2}{|c}{} \\
\hline
\end{tabular}

\section{S ScholarONE \\ Manuscript Central}




\title{
Terms of Trade Shocks and the Current Account in \\ Small Island Developing States
}

\begin{abstract}
The paper investigates the dynamic relationship between external and internal shocks and the current account in selected small island developing states. External shocks, defined as terms of trade fluctuations, explain a significant proportion of the variation in the current account balances. The external shocks have a temporary negative impact on the current account balances with a subsequent improvement, generating a J-curve type reaction. In contrast, real output shocks have a positive and significant effect on the current account.
\end{abstract}

Keywords: terms of trade shocks, current account balance, panel data, VAR, small islands developing states.

JEL classification numbers: C33, E21, F32 


\section{Terms of Trade Shocks and the Current Account in \\ Small Island Developing States}

\section{Introduction}

Small island developing states (SIDS) face a greater risk of marginalisation from global economic activities than other developing countries. The problem results from their small size, remoteness from large markets, and vulnerability to economic and environmental shocks. Although SIDS are characterised by significant openness to international trade, they face low diversification in production and exports, which further increases the vulnerability to adverse fluctuations and shocks in world markets, and constrains their export earnings potential. This is evident in the historically unstable terms of trade and the highly volatile economic performance of these countries (see Briguglio, 1995; Armstrong and Read, 1998).

Understanding terms of trade patterns is a topic of interest in the development literature. The seminal work of Prebisch (1950) and Singer (1950) - the Prebisch-Singer hypothesis suggests that the relative prices of primary commodities have a tendency to decline. Therefore, the impact of terms of trade deterioration, that is, import prices rising faster than export prices, other things being the same, is to worsen the balance of payments at a given growth rate (Thirlwall 2003). The impact of terms of trade shocks on a country's current account balance is also a key issue in international economics. Various theoretical frameworks predict that an adverse shock to the terms of trade will worsen the current account (e.g. Harberger 1950, Laursen and Metzler 1950). However, other studies hold that the impact depends on the duration of the shock (e.g. Obstfeld and Rogoff 1995). 
The paper investigates the effects of terms of trade shocks on the current account in a selection of SIDS from Africa, the Caribbean, East Asia and the Pacific. In spite of the advances on the theoretical front, existing empirical evidence for developing countries is limited. The paper contributes to our understanding of the topic by reviewing the specialisation patterns in small islands by sector, industry and technology content, as well as the dynamics of terms of trade volatility and external shocks. The study applies the panel vector autoregression (VAR) approach in modelling the relationship between terms of trade shocks and the current account.

The analysis reveals that external shocks, defined as terms of trade fluctuations, explain a significant proportion of the variation in the current account balances. External shocks have a negative impact on the current account balances, although on a temporary basis, reflecting a $J$ curve type reaction. Real output shocks, conversely, have a positive and significant effect on the current account.

The rest of the paper proceeds as follows. Section 2 discusses the evolution of the terms of trade and the current account shocks in 12 SIDS. Section 3 examines the relevant theory and empirical evidence. Section 4 describes the empirical methodology, estimates the econometric models and discusses the results. Section 5 concludes.

\section{Terms of trade and the current account in SIDS}

The secular deterioration of developing countries' commodity or net barter terms of trade has significant consequences for developing countries prospects, as underlined by Singer (1950) and Prebisch (1950) and the subsequent literature. Small island developing states are beset by 
commodity price fluctuations due to their highly specialised production and export activities, which affect their terms of trade and, in turn, other economic outcomes. In general, world commodity prices are highly volatile, and this translates into large terms of trade fluctuations for primary commodity-exporting countries such as SIDS. This has two important connotations. On the one hand, there are the implications for primary commodities relative to manufactures, and on the other, for the terms of trade of developing countries relative to developed ones. ${ }^{1}$ Although different, there is considerable overlap between the two phenomena.

Terms of trade volatility in small islands could be explained by two dynamics. First, the share of trade in GDP (i.e. openness) is especially large in small states, and this may contribute to magnifying the impacts of terms of trade shocks. Second, SIDS exports are prone to be more specialized than those of large states, both in terms of the products exported and their export markets (Kuznets 1960; Armstrong and Read 1998). In this regard, Figure 1 depicts the high concentration of exports on primary products and resource-based manufactures, particularly in small islands from the Pacific and Africa regions. Consequently, the average prices of their exports and imports might be more volatile than in countries with more diversified trade patterns. ${ }^{2}$

(Figure 1 about here)

High population growth rates, migration, and a lack of diversification in production further exacerbate the terms of trade shocks impact on the variability of national incomes (Cashin and Loayza, 1995). For instance, Browne and Scott (1989) explain the high variability in the Pacific islands' national income mostly as a result of limited agricultural production, emigration to New Zealand and Australia, and low diversification in production. Thirlwall (1991) examines the exports and balance of payments performance of the Pacific island economies in 
relation to the movements in commodity prices and the extent to which changes in export earnings have been dominated by terms of trade volatilities. The study confirms that Pacific island economies are extensively dependent on the production and export of primary commodities. Hence, the instability of primary product prices has had detrimental consequences on the balance of payments and on the economic performance of such countries.

Servén (2000) shows that Latin American and Caribbean countries have suffered significant terms of trade disturbances - similar to developing economies in South Asia and the Middle East and North Africa. A key factor explaining the large terms of trade variability is the high share of a few primary commodities, minerals and resource-based manufactures in the total exports of many of the region's economies.

Terms of trade volatility was high during the 1970s (largely reflecting the first oil crises), and abated somewhat in the 1980s and more so in the 1990s, both in small island developing states and other world regions. Table 1 reveals the high variability and dispersion in the terms of trade experienced by SIDS, especially in Western Africa (such as Cape Verde, Comoros and Guinea-Bissau). This phenomenon could be explained by the low levels of diversification in such countries, where production and exports are concentrated in a limited range of commodities, as already discussed. Changes in terms of trade are also affected by reductions in the prices of manufactured goods, higher raw material prices, and exchange rate fluctuations, amongst other factors. ${ }^{3}$ According to Baxter and Kouparitsas (2000), terms of trade fluctuations are twice as large in developing countries as in developed countries. The authors attribute this pattern to developing countries' reliance on commodity exports, which prices are more volatile than those of manufactured goods. Furthermore, Small developing countries, notably SIDS, are exceptionally 
exposed to terms of trade fluctuations because they have little, if any, influence over their export prices (Broda, 2004).

(Table 1 about here)

High terms of trade volatility concurs with variable changes in their current account balances and real output, as can be noted in Figures 2 and 3. ${ }^{4}$ On average, the terms of trade show a negative historical trend, in line with significant fluctuations in the current account as a share of GDP. This tendency is observed in most of the countries, particularly those highly susceptible to negative shocks resulting from primary commodities and resource-based manufactures volatilities (e.g. Jamaica and Trinidad and Tobago in the Caribbean; Fiji and Papua New Guinea in the Pacific; and, Seychelles, Sao Tome and Principe in the Indian Ocean and Africa). Real GDP growth rates are, as well, more volatile in small states, owing to their high exposure to international trade (predominantly imports) and fluctuations in their terms of trade. However, there is a significant variability amongst countries, and between and within regions regarding fluctuations of the variables under scrutiny, as noted in Table 1.

(Figures 2 and 3 about here)

The evolution of the current account in SIDS has been determined by both domestic and international market environments. In the late 1970s global market conditions were adverse for most developing countries, chiefly to net commodity importers - of which SIDS are a notable subset. As in the case of terms of trade volatility, large current account deficits (mostly doubledigit) reflected the second oil-debt crises in the late 1970s. Subsequent gradual improvements in the current account and balance of payments relate to progress in domestic policies and favourable conditions in international markets. 
The end of the 1980s and early 1990s were also marked by turbulent macroeconomic conditions in the global economy, affecting the developing world mostly through exchange rates and balance of payments crises. These conditions aligned significant reform efforts, backed by international financial institutions, development agencies and donors' efforts, and entailed a change in production and trading patterns, mostly in larger SIDS. Structural reforms and trade liberalisation helped to increase foreign capital inflows - predominantly foreign direct investment, representing an important additional source of investment and a potentially critical contributor to growth and the sustainability of balance of payments in SIDS.

The next phase of gradual improvements, which started in the mid-1990s, coincided with structural changes in the global trade architecture, notably selected phasing out of trade preferences for agricultural products, and the modification of guaranteed prices for apparels (i.e. the phasing out of the multi-fibre agreement), as well as competition from other developing countries in the production of manufactures (notably China). But, to a limited extent this has occurred within the WTO and due to the EU preferences (e.g. the Everything but Arms, EBA scheme), but is not a feature of EPAs - if anything they preserve ACP preferences].These have significant implications for SIDS that specialise in manufactures exports, such as the Dominican Republic and Mauritius. During the period, terms of trade movements are also highly correlated with current account developments, and particularly until the mid 1990s.

With this background, the paper proceeds to discuss the theoretical framework relating external and internal shocks to the current account and estimating how terms of trade fluctuations and real income changes impact the current account in the short term using panel vector autoregression (VAR). 


\section{Terms of Trade Shocks and the Current Account}

\section{1: Theory and Evidence}

The impact of terms of trade shocks on a country's current account balance is one of the most debated subjects in international economics. A major contribution is the Harberger-LaursenMetzler (Harberger 1950; Laursen and Metzler 1950) theory, which predicts that an adverse shock to the terms of trade will worsen the current account balance (known as the HarbergerLaursen-Metzler effect). The original work envisaged that a terms of trade deterioration should lead to a fall in savings and a current account deficit: Harberger discussed the effect on the trade balance of a devaluation, and Laursen and Metzler examined the transmission of disturbances in a two-country world with endogenous terms of trade and balanced trade, looking at the effects on spending of a terms of trade change.

However, other theoretical frameworks and empirical studies state that the relationship between terms of trade and current account is ambiguous. In models that hold the current account balance as the outcome of forward-looking dynamic savings and investment decisions, the impact depends on the duration of the shock (examples of these models include the intertemporal approach to the current account, Obstfeld and Rogoff 1995).

On empirical grounds, the effect of a terms-of-trade shock on the current account depends, to a certain extent, on the duration (transitory or permanent) and agents' expectations about the shock, that is, if the shock was anticipated or unanticipated by agents. There are other determinants that affect the direction of the Harberger-Laursen-Metzler effect such as the type and significance of the transmission channel. 
These models, which have been extended in different fashions, try to explain the various channels through which the terms of trade affect the current account (i.e. savings, investment, and consumption). ${ }^{5}$ For instance, Edwards (1989) analyses how temporary terms of trade shocks influence the current account, allowing for differences between disturbances to the internal terms of trade generated by tariff changes, and instability to the external terms of trade. The author shows that changes in the (equilibrium) real exchange rate —or relative price of non-tradablesare a crucial channel through which a change in the terms of trade affects the current account.

Cashin and McDermott (2002) study several features of the terms of trade patterns of five commodity-exporting OECD countries and the relationship between terms of trade shocks and the current account balance. The paper shows that median shocks to the terms of trade are highly persistent, albeit with a large transitory component, and that they account for a small proportion of the variability of the current account balances in Canada, the United Kingdom and the United States, in contrast to the relatively large share of the variability of the external balances in Australia and New Zealand.

Considering the existing literature, the impact of the terms of trade on the current account is regarded as theoretically ambiguous. Specifically, an unfavourable shock in the terms of trade will have three effects: first, the consumption smoothing effect (or Harberger-Laursen-Metzler effect) which results from the reduction in national income relative to future national income; second, the consumption tilting effect that results from the increase in the current price of imports relative to the future price of imports; and, third, the real exchange rate effect, consisting of the increase in the price of imported goods relative to the price of non-tradables. In response to an adverse transitory shock in the terms of trade, private savings will fall if the consumptionsmoothing effect dominates the saving enhancing implications of the consumption-tilting and 
real exchange rate effects. Otherwise, savings will rise if the consumption smoothing is weaker than the other two effects.

\subsection{Identification of the shock to the current account}

Our aim is to identify the impact of external and domestic shocks to the current account through changes in the terms of trade and output (real GDP). The paper follows Ahmed and Park (1994) and Cashin and McDermott (2002), which extend the open economy framework proposed by Blanchard and Quah (1989) to an open economy setting, using vector auto-regression models to identifying the major sources of economic shocks.

SIDS are small open economies, which produce and trade goods and services with the rest of the world at exogenously given external terms of trade, and other international prices. The determinants of the balance of trade (and the current account), are explained based on the behaviour of domestic absorption, defined as the sum of consumption, investment and government spending, as predicted by the Harberger-Laursen-Meltzer theory. Following Ahmed and Park (1994), the growth of domestic absorption is defined as:

$\Delta y_{d t}=\alpha_{d}(L) \mu_{t}+\beta(\boldsymbol{L}) \varepsilon_{t}+\gamma_{d}(L) \Delta \nu_{t}+\delta_{d}(L) \Delta \mathrm{u}_{z}$

where $y_{d t}$ is domestic absorption, $\Delta$ is the first difference operator, $L$ is a finite order polynomial in the lag operator, $\mu$ is a white noise disturbance representing real shocks originating in the rest of the world, $\varepsilon$ is the domestic supply shock, $v$ is the domestic absorption shock, and $u$ represents the domestic price level shock. To the extent that supply and demand shocks (both domestic and international) have persistent effects on output, they increase permanent income, and hence domestic absorption. In this framework, the trade balance $(B)$, 
defined as the difference between domestic output $(y)$ and domestic absorption $\left(y_{d t}\right)$, can be expressed as:

$B \equiv y_{t}-y_{d t}=\alpha_{1}(L) \mu_{t}+\alpha_{2}(L) \varepsilon_{t}+\alpha_{3}(L) \Delta v_{t}+\alpha_{4}(L) \Delta \mathrm{u}_{t}$

where polynomials are functions of the lag-operator polynomials in equation (1).

The main concern of this study is the response of the current account, that is, the sum of the trade balance $(B)$, net factor income, and net transfer payments to external and domestic shocks. That is, what is the impact of terms of trade movements and real GDP changes on the current account? Therefore, following equations (1) and (2) and substituting the terms of trade and real GDP for $\left(\mu_{t}\right)$ and $\left(\varepsilon_{t}\right)$ respectively, the external and domestic shocks to the current account of the balance of payments $(\mathrm{ca})$ can be characterised as follows:

$c a_{t}=c_{1}(L) T O T \mu_{t}+c_{2}(L) y_{t}$

\section{Empirical analysis}

\subsection{Panel data vector autoregression}

This empirical exercise aims at examining how terms of trade disturbances affect the current account balances in the economies under study. Due to data constrains, which makes it difficult to employ time series analysis for individual countries, such as a Structural VAR, the paper applies the panel data vector autoregression (VAR) approach. Panel data VAR represents an interesting challenge due to the likely presence of cross-sectional heterogeneity. This 
methodology links the traditional VAR technique, which captures the evolution and the interdependencies between a set of ' $n$ ' time series (or endogenous variables) measured over the same sample period $(t=1, \ldots, T)$ as a linear function of their past evolution $(t-1)$, with panel-data methodology, which allows for individual (country) heterogeneity. The asymptotic properties and advantages of estimating VARs with panel data are discussed by Holtz-Eakin, Newey and Harvey (1988), and Gilchrist and Himmelberg (1998).

Orthogonalised impulse response functions are used, which help to illustrate the response of one variable of interest (i.e., the current account normalized by nominal GDP) to a shock in another variable of interest (terms of trade and real GDP changes). Also, impulse-response functions allow identifying one shock at a time while holding other innovations constant. ${ }^{6}$

A first-order panel VAR model can be specified as:

$$
c a_{i t}=\alpha_{i}+y_{t}+z_{i t} b+e_{i t}
$$

where $c a$ represents the current account to GDP ratio; $\alpha_{i}$ and $y_{t}$ are the country and time specific effects in panel data; $z_{i t}$ is a vector of lagged endogenous variables $\{c a, t o t, r y\}$, that is, tot represents the net barter terms of trade, $r y$ (real GDP), and $e_{i t}$ is the idiosyncratic error term. The model also considers country-specific time dummies to explain aggregate shocks that may affect all countries equally.

\subsection{Impulse responses estimations}

4.2.1 Sample and Data 
In this paper, small islands developing states (SIDS) follows the United Nation's classification, which includes coastal countries that share similar sustainable development drawbacks. A sample of 13 SIDS from Africa, the Caribbean, and the Pacific were selected mainly due to data availability, which is a major constraint particularly in less developed SIDS. A list of countries covered is presented in Table A1. These small states hold unique vulnerabilities, which tend to augment the volatility of the current account compared to larger states. As far as the empirical analysis of shocks to the current accounts is concerned, the paper focuses on terms of trade and real income shocks, as explained in the previous section. The definition of the variables and data sources is also detailed in the Appendix.

(Table 2 about here)

\subsubsection{Results}

Table 2 reports the estimated coefficients of the panel VAR system presented in Equation 4. ${ }^{7}$ These coefficients are the result of the estimated impulse response functions. In this regard, two different types of shocks are identified in this paper, in the spirit of the Harberger-LaursenMetzler theory: (i) an external shock, quantified by innovations to the terms of trade; and (ii) a temporary 'demand shock', identified by the response of the current account ratio to changes in real GDP. The main underlying assumptions in identifying these shocks are that the terms of trade shocks are exogenously given, and that demand disturbances have no long-run impact (i.e., the demand shock is transitory). ${ }^{8}$

As far as the external shock is concerned, the results imply that the response of the current account to innovations in the terms of trade is negative, as shown by the estimated coefficients from the panel VAR. However, this shock on the current account is temporary, and 
this is also graphically represented in Figure 4 (panel a). The impulse response analysis shows an initial negative shock of the terms of trade to the current account persisting for up to two years. This is a $J$-curve type response, as the short term movements in the terms of trade can worsen the current account (and the overall balance of payments), due in part to inelastic demand for exports and imports. ${ }^{9}$

Moving on to the domestic shock, output (GDP) changes have a positive (temporary) and significant effect on the current account fluctuations, as indicated by the positive coefficient. However, the initial shock disappears after two years as portrayed in panel (b) in Figure 4.

We also consider the impact of terms of trade and current account shocks on real output. The results suggest that, in all cases, real output reacts negatively to external shocks. This relates to Easterly and Kraay (2000), who find that small states present greater volatility of annual growth rates which is, in part, explained by these countries sensitivity to terms of trade shocks. ${ }^{10}$ The terms of trade based volatility is, in turn, due to small states' exposure to (and dependence on) international trade as discussed earlier, mainly export volatility. ${ }^{11}$

For countries that benefit from compensatory mechanisms or insurance, which tend to be costly, the negative impact of shocks on growth does not necessarily involve growth instability. Nevertheless, growth volatility, even though showing some decline in the 1990s, is high in the developing countries, and has been higher in SIDS and Least Developed Countries (LDC) compared to other developing countries.

The non-permanent feature of the shocks identified in this study could be explained by the significant role of policy factors on reducing volatility (Combes et al, 2000; Easterly et al, 2001). Improvements in economic policy implementation and institutions, alongside foreign aid, 
have played a part in reducing the negative consequences terms of trade deterioration and other exogenous shocks, and these are not necessarily captured by the short run atheoretical VAR. For example, Funke et al (2008) emphasise the role of 'policies' in achieving fast recovery after persistent negative terms of trade shocks for a sample of 159 countries over three decades. The authors confirm that fast recovery is associated, pari passu, with improvements in the government's stability and institutional environment. Importantly, timely donor support is conducive to absorbing the shock.

In relation to the role of foreign resources, Santos-Paulino (2007) assesses the marginal relationship between capital flows (i.e. aid flows) and import growth and the balance of payments in Least Developed Countries (LDC). For LDCs, official development assistance remains the most important source of foreign capital, amounting to more than 20 percent of imports and over 10 percent of GDP. The study empirically confirms the links between the liberalisation commitments and financial resource inflows.

\section{Conclusion}

This paper analyses the influences of terms of trade shocks on the current account in selected small island developing states. The findings suggest that the terms of trade innovations have a negative impact on the current account balances. However, this effect is transitory, as the current account balances reflect a $J$-curve type reaction to terms of trade variations. Real output also reacts negatively to changes in the terms of trade. SIDS sources of vulnerability mostly relate to their intrinsic economic and geographic characteristics, as well as to external factors, which in turn affect balance of payments positions, such as high variability of supply and demand, low 
price elasticities for their exports, excessive specialization of production and trade (mostly in one or two commodities), and high concentration of exports in particular markets.

The findings bring our attention to the optimal policy response to confront the repercussions of external adverse shocks, in particular terms of trade volatility, for small islands and least developed countries, the majority of which are categorized as fragile or vulnerable. Under these circumstances, risk management policies to deal with aggregate volatility (i.e., terms of trade, financial system, international capital flows, fiscal policy, and monetary and exchange rate system policy) become imperative. Several guidelines have been put forward, aimed at addressing terms of trade volatilities (see for example, Servén, 2000). These include: international portfolio diversification; self-insurance, based on stabilization funds; and self protection, consisting mostly of trade diversification and the appropriate trade policy package, that is, trade taxes and subsidies. Some policies address more than one source of instability, or combine two or more of the insurance aspects.

In terms of financing, traditionally, small islands have benefited from income or buffer stock compensation schemes such as IMF's Compensatory Financing Facility (CFF), the Stabex Scheme under Lomé (and Cotonou) conventions, or the European Development Fund. Whether these schemes should be further promoted and enhanced, or new efforts should be put forward remains an important research and policy agenda issue.

The effectiveness of such insurance schemes has been widely discussed (see, for instance, Collier et al. 1999; and Guillaumont in this volume). The literature and policy experiences show that the challenge is to compensate negative shocks in an effective and timely manner, at the same time promoting good governance to improve absorptive capacity, mitigating moral hazard. 
Alternative proposals include combining the transfer of resources, by means of debt service regulation linked to the evolution of the terms of trade, or through a special fund for countries with low levels of indebtedness. The proposal, contrary to the CFF and Stabex schemes, will contribute to strengthening countries' and agents' ownership of the resources and outcomes.

Finally, as part of a long term development strategy, it is imperative for the small island developing states (and low and middle income economies in general) to diversify their output and export structures in favour of commodities and economic activities with more advantageous production and demand characteristics. In practice, however, this is difficult to achieve as it is the restricted endowments and capabilities that determine the narrow production and export structures. 
Figure 1

Mean export composition in Small Island developing states by main sectors, 1980-2005

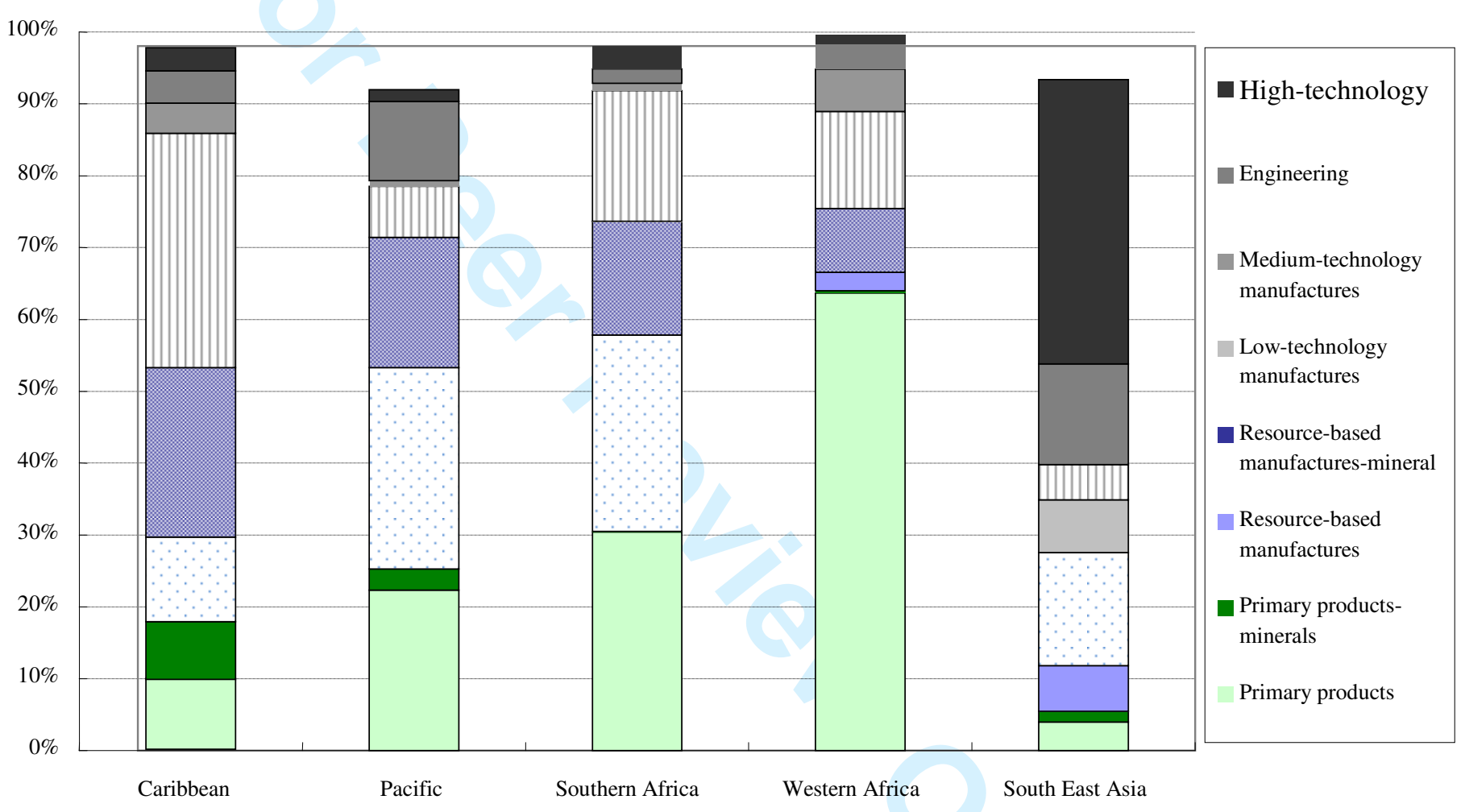

Note: * Arithmetic mean. Data availability varies by region. Series may not add to $100 \%$ due to averages. The export baskets are classified using Lall's (2000) industry taxonomy, which ranks exports according to their technology content, and helps to identify the sectors which promote dynamic comparative advantages. The sample includes the SIDS defined in Table A1, and South East Asia refers to Singapore. Detailed mean export composition by country is presented in Tables A3 and A4 in the appendix.

Source: Author's own calculations using UNCTAD's COMTRADE (3-digits SITC Rev2). 
Figure 2: Terms of Trade and Current Account Evolution in SIDS (1978-2006)

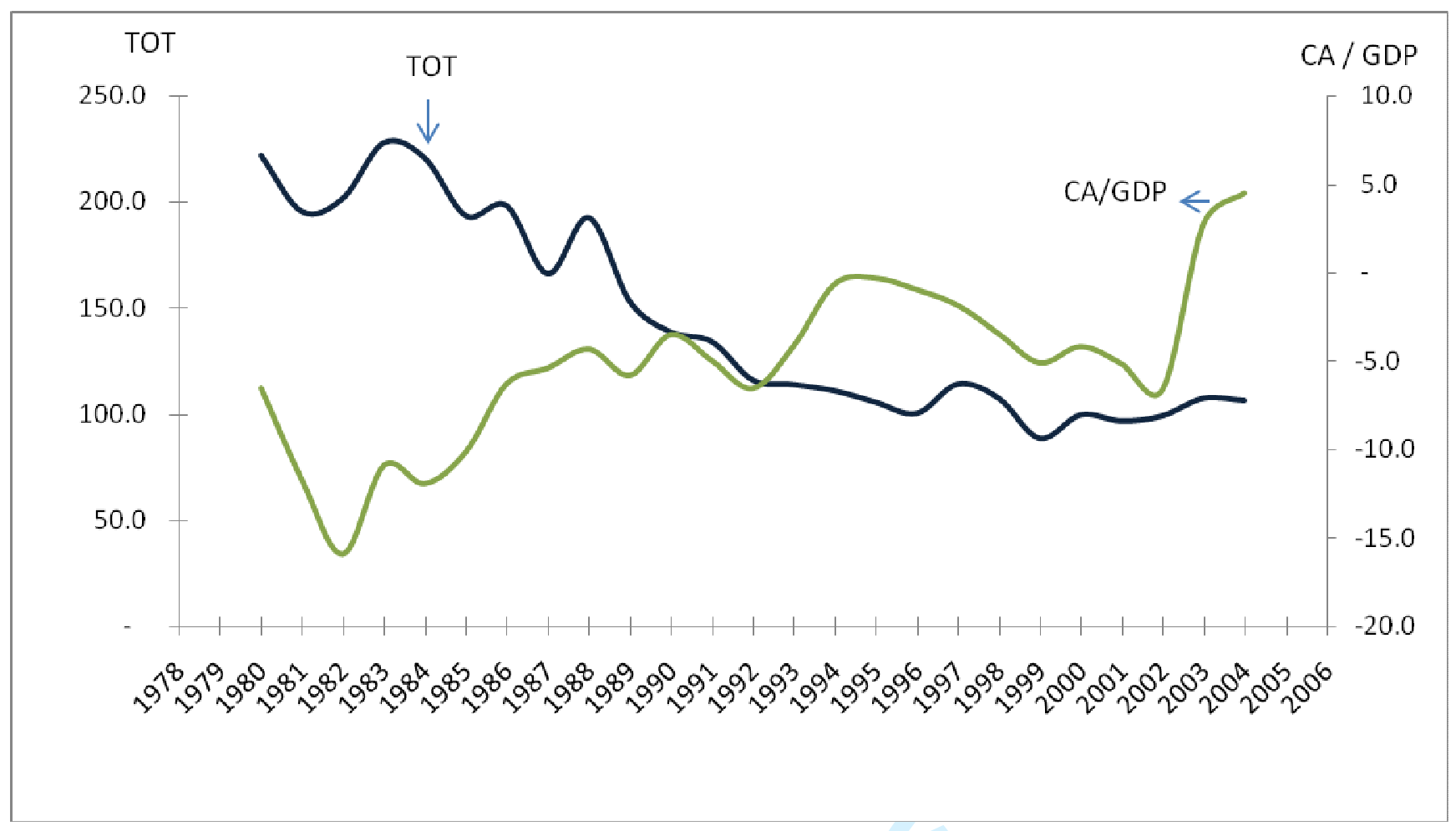

Note: Terms of trade (TOT $2000=100$, left scale); Current Account as share of nominal GDP (US\$; right scale). Author's elaboration based on the sample defined in Table A1. 
Figure 3: Terms of Trade and Real GDP Growth in SIDS (1978-2006)

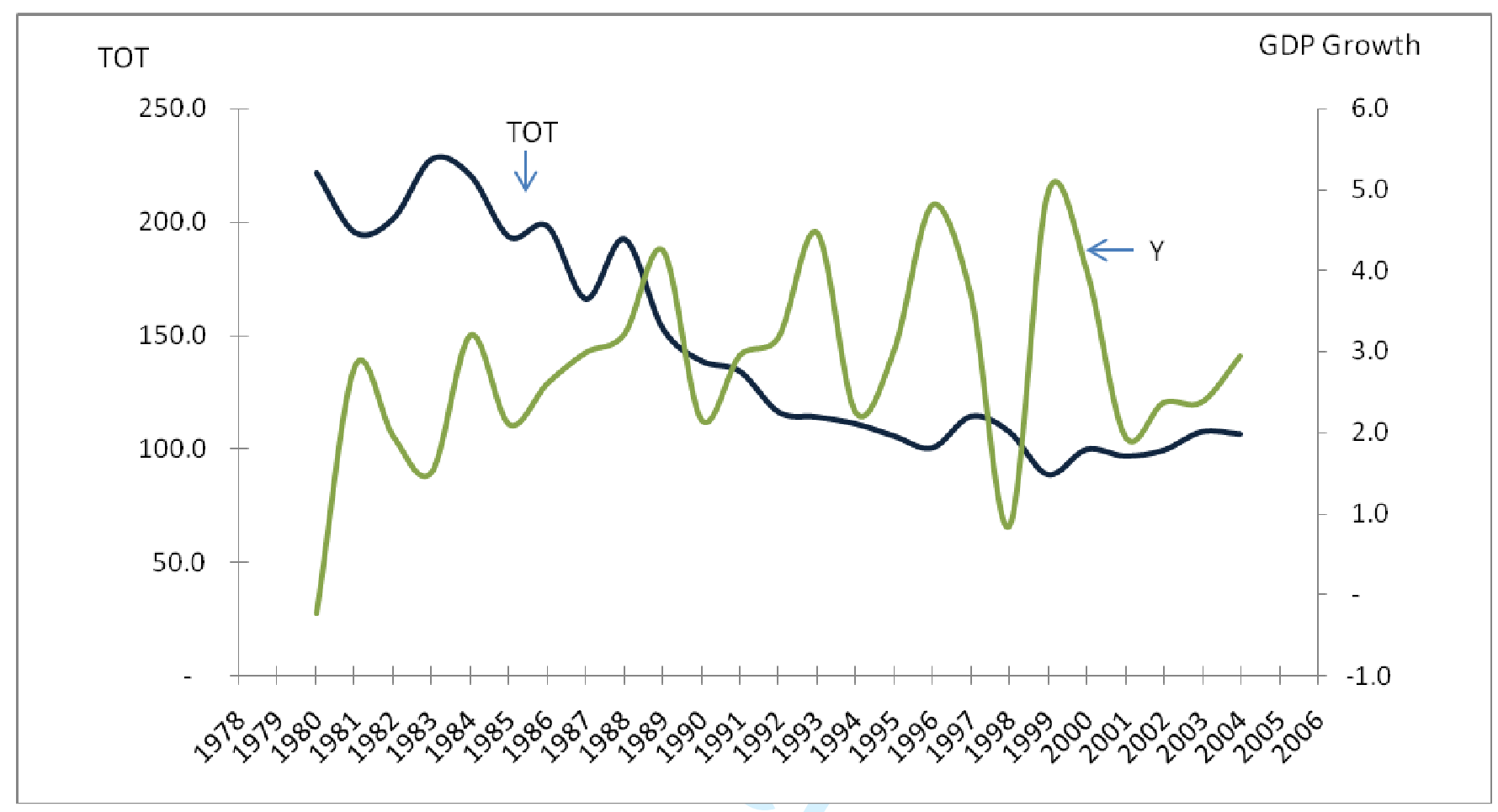

Note: Terms of trade (TOT $2000=100$, left scale); real GDP growth $(2000=100$; right scale). Author's elaboration based on the sample defined in Table A1. 
Table 1: Summary statistics for the variables in the VAR models, 1980-2005 a)

9

\begin{tabular}{|c|c|c|c|c|c|c|c|c|c|c|c|c|c|}
\hline $\begin{array}{l}10 \\
11 \\
12\end{array}$ & & \multicolumn{3}{|c|}{$\begin{array}{c}\text { All } \\
(\mathrm{N}=13, \\
\text { Obs. }=362)\end{array}$} & \multicolumn{3}{|c|}{$\begin{array}{c}\text { Africa } \\
(\mathrm{N}=7, \text { Obs. }=181)\end{array}$} & \multicolumn{3}{|c|}{$\begin{array}{c}\text { Caribbean } \\
(\mathrm{N}=4, \text { Obs. }=103)\end{array}$} & \multicolumn{3}{|c|}{$\begin{array}{c}\text { Pacific } \\
(\mathrm{N}=3 \text {, Obs. }=78)\end{array}$} \\
\hline 14 & & Mean & SD & $\mathrm{CV}$ & Mean & SD & $\mathrm{CV}$ & Mean & SD & $\mathrm{CV}$ & Mean & SD. & $\mathrm{CV}$ \\
\hline 15 & TOT & 142.5 & 146.9 & 103.4 & 148.3 & 184.5 & 124.5 & 149.1 & 102.5 & 68.7 & 99.9 & 55.9 & 55.9 \\
\hline $\begin{array}{l}16 \\
17\end{array}$ & $\begin{array}{l}\text { Current } \\
\text { Account }\end{array}$ & -5.4 & 12.4 & -228.1 & -11.5 & 13.1 & -114.1 & -2.9 & 4.9 & -163.7 & -2.3 & 10.6 & -464.3 \\
\hline 18 & GDP growth & 2.9 & 4.8 & 165.9 & 3.2 & 4.4 & 138.8 & 1.9 & 4.3 & 228.1 & 1.9 & 4.7 & 236.0 \\
\hline
\end{tabular}

Notes: ${ }^{a}$ ) The sample period (i.e. data availability) varies across countries. The sample includes all SIDS in Table A1, excluding Singapore. ${ }^{\text {b }) ~ S D ~ i s ~ t h e ~ s t a n d a r d ~ d e v i a t i o n, ~ a n d ~ C V ~ t h e ~ c o e f f i c i e n t ~ o f ~ v a r i a t i o n, ~}$ formulated as the ratio of the standard deviation to the mean. ${ }^{c}$ ) All ratios are reported as percentages. 
Table 2

Main results of VAR Impulse Response Estimates

Notes: ${ }^{\text {a) }}$ The reported coefficients are the median unbiased estimations from the vector autogression (VAR) estimations. That is, a one unit shock to the residuals of a VAR equation produces a deviation of a given variable from its mean value which amounts to the size of the impulse response. . ${ }^{\text {b) }}(t-1)$ refer to one year lag operator. ${ }^{c)}$ Numbers in brackets (.) are t-statistics. The estimations include SIDS presented in Table A1, excluding Singapore. 
2

3

4

5

6

7

8

9

10

11

12

13

14

15

16

17

18

19

20

21

22

23

24

. 25

26

27

28

29

30

31

32

33

34

35

36

37

38

39

40

41

42

43

44

45

46

47

48

49

50

51

52

53

54

55

56

57

58

59

60

\section{Figure 4}

Dynamic responses to a current account shock: (a) Terms of Trade and (b) Real GDP
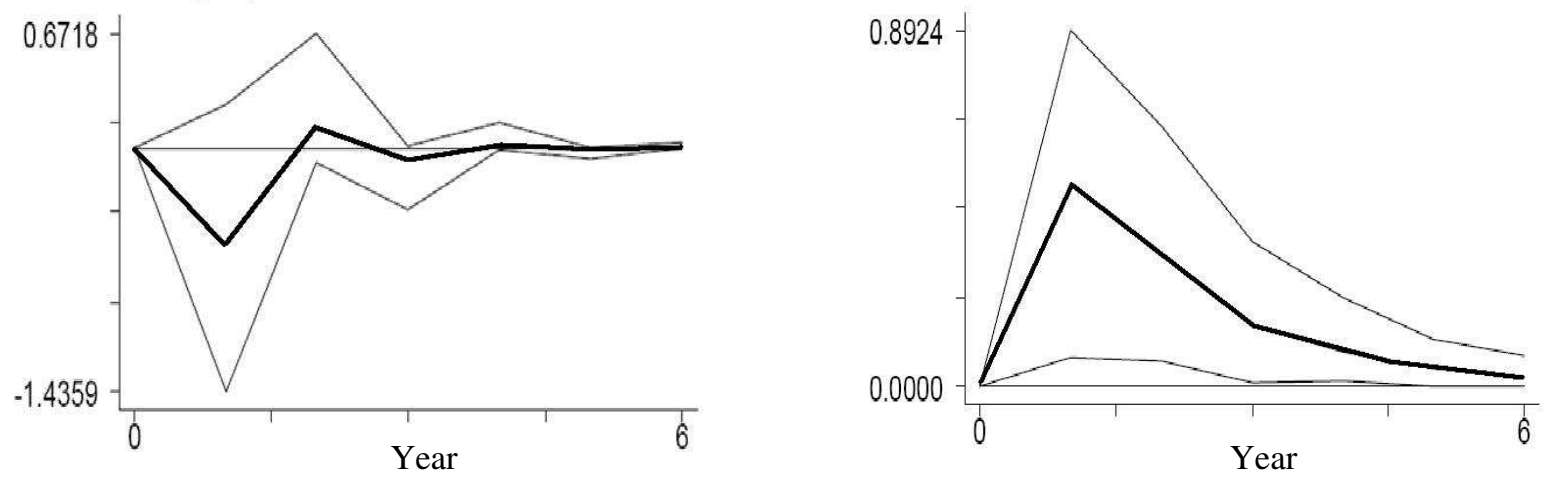

(a) Terms of Trade

(b) Real GDP

Note: The smooth lines_are 95 percent point-wise probability bands generated by Monte Carlo interactions. Mean values for sample in Table 2. 
NOTES

${ }^{1}$ A related discussion is whether globalisation ameliorates the extensively reported decline in the terms of trade of primary commodities. For instance, Blattman, Hwang and Williamson (2003) argue that exogenous relative price shocks associated with the external terms of trade, especially during periods of globalisation (or disintegration) when commodity prices converge (or diverge), induce large terms of trade changes and economy-wide responses. However, evidence for the United States (US), an advanced economy highly integrated with the rest of the world, demonstrates that the decline in commodity terms of trade is not directly related with the process of globalisation. This indicates that, in the case of the US, neither more integration nor protectionist measures would affect this trend (Mollick et al, 2008).

2 Table A1 presents the export diversification and concentration indexes for our sample of countries. The high concentration of exports in SIDS is also confirmed by the HerfindahlHirschmann index where African SIDS, such as Comoros, Guinea-Bissau, and Sao Tome and Principe in particular are close to maximum specialisation (i.e., the index is nearly 1).

3 Kaplinsky and Santos-Paulino (2005) show that the greater the technological content, the smaller the percentage (or the lower the prevalence) of products registering price falls.

4 Figures $\mathrm{A} 1$ and $\mathrm{A} 2$ in the appendix show the terms of trade, the current account balances to GDP ratios, and real GDP growth by country.

${ }^{5}$ Important references to such models include Sachs (1981), Obstfeld (1982), Dornbusch (1983), Svensson and Razin (1983), Obstfeld and Rogoff (1995).

6 The estimations are done using the STATA programme developed by Love and Zicchino (2004). Impulse response functions and their confidence intervals are constructed from the estimated VAR coefficients, where the standard errors of the impulse response functions are 
computed using Monte Carlo simulations. The panel VAR approach allows for individual heterogeneity by introducing fixed effects. Fixed effects are removed by the Helmert procedure or forward mean differences, whereas time dummies are eliminated by subtracting the means of each variable calculated for each country-year. This transformation preserves the orthogonality between transformed variables and lagged regressors; therefore, lagged regressors can be used as instruments (see Arellano and Bover 1995; Love and Zicchino 2004).

7 This paper focuses on low and middle income small island states. Further estimations were undertaken including Singapore, a high income SIDS that specialises in manufactures and hightechnology exports in contrast to other countries in the sample. Although Singapore is also vulnerable to external business cycles and other natural hazards inherent to small islands, it is less exposed to fluctuations in the terms of trade as far as the price of primary commodities is concerned. The inclusion of Singapore did not alter the results significantly.

8 This restriction follows Blanchard and Quah (1989). They show that fluctuations in output (GNP) and unemployment are affected by supply disturbances, which have a permanent effect on output, and demand shocks, which are transitory. Cashin and McDermott (2002) also identify a permanent 'supply shock', measured by changes in the growth of real output (GDP) for OECD countries.

${ }^{9}$ Providing that the elasticities of demand for imports and exports are greater than one in the longer term, the trade balance will improve over time, as stipulated by the 'Marshall-Lerner' condition. See, for example, Santos-Paulino and Thirlwall (2004) for further elaboration on this issue. 
10 Although terms of trade fluctuations are not the only determinant of economic performance in small island states, the authors show that even after controlling for terms of trade volatility, growth rates in small states are significantly more volatile than in non-small states.

${ }^{11}$ Easterly et al (1993) show that terms of trade shocks explains part of the variance in growth across countries. See also Broda (2004). 


\section{References}

Ahmed, S. and Park, J.H. (1994) 'Sources of macroeconomic fluctuations in small open economies', Journal of Macroeconomics, 16 (1), pp. 1-36.

Arellano, M. and Bover, O. (1995) 'Another Look at the Instrumental Variable Estimation of Error-Components Models'. Journal of Econometrics, 68 (1), pp. 29-51.

Armstrong, H. W. and Read, R. (1998) 'Trade and Growth in Small States: The Impact of Global Trade Liberalization', World Economy, 21 (4), pp. 563-585.

Baxter, M. and Kouparitsas, M. (2000) 'What Causes Fluctuations in The Terms of Trade?', NBER Working Paper 7462, National Bureau of Economic Research (Cambridge: MA).

Blanchard, O.J. and Quah, D. (1989) 'The Dynamic Effects of Aggregate Demand and Supply Disturbances', American Economic Review, 79 (4), pp. 655-673.

Blattman, C., Hwang, J., and Williamson, J.G. (2003) 'The Terms of Trade and Economic Growth in the Periphery 1870-1983', NBER Working Paper 9940, National Bureau of Economic Research (Cambridge: MA).

Briguglio, L. (1995) 'Small Island Developing States and their Economic Vulnerabilities'. World Development, 23 (9), pp. 1615-1632.

Broda, C. (2004) 'Terms of trade and exchange rate regimes in developing countries', Journal of International Economics, 63 (1), pp. 31-68.

Browne, C. and Scott, D.A. (1989) Economic Development in Seven Pacific Island Countries, International Monetary Fund, (Washington: DC).

Cashin, P. and McDermott, J.C. (2002) 'Terms of Trade Shocks and the Current Account: Evidence from Five Industrial Countries'. Open Economies Review, 13 (3), pp. 219-235. 
Cashin, P. and Loayza, N. (1995) 'Paradise Lost? Growth, Convergence, and Migration in the South Pacific'. IMF Staff Papers No. 42, (Washington: DC), pp. 608-641.

Collier, P., Guillaumont, P., Guillaumont, J., and Gunning, J. (1999) 'Reforming Stabex', World Economy, 22 (5), pp. 669-82.

Combes, J.-L. and Guillaumont. P. (2002) 'Commodity Price Volatility, Vulnerability and Development', Development Policy Review, 20 (1), pp. 25-39.

Dornbusch, R. (1983) 'Real Interest Rates, Home Goods, and Optimal External Borrowing'. Journal of Political Economy, 91 (1), pp. 141-153.

Easterly, W., Kremer, M. Prichett, L. and, Summers, L.H. (1993) 'Good Policy or Good Luck' Country Performance and Temporary Shocks, Journal of Monetary Economics, 32 (3), pp. 549-583.

Easterly, W. and Kraay, A. (2000) 'Small States, Small Problems? Income, Growth, and Volatility in Small States', World Development, 28 (11), pp. 2013-2027.

Easterly, W., Islam, R., and Stiglitz, J. (2001) 'Shaken and Stirred: Explaining Growth Volatility'. In B. Pleskovic and N. Stern (eds), Annual Bank Conference on Development Economic, World Bank (Washington: DC), pp. 191-213.

Edwards, S. (1989) 'Temporary Terms-of-Trade Disturbances, the Real Exchange Rate and the Current Account', Economica, 56 (223), pp. 343-357.

Funke, N., Granziera, E., and Iman, P. (2008) 'Terms of Trade Shocks and Economic Recovery', IMF Staff Papers, 36 (February).

Gilchrist, S. and Himmelberg, C. (1998) 'Investment, Fundamentals and Finance, NBER Working Paper No. 6652, National Bureau of Economic Research (Cambridge: MA). 
Harberger, A (1950) 'Currency Depreciation, Income and the Balance of Trade'. Journal of Political Economy, 58 (1), pp. 47-60.

Holtz-Eakin, D., Newey, W., and Harvey, S.R. (1988) 'Estimating Vector Autoregressions with Panel Data'. Econometrica, 56 (6), pp. 1371-1395.

Kaplinsky, R. and Santos-Paulino, A.U. (2005) 'A Disaggregated Analysis of EU Imports: The Implications for the Study of Patterns of Trade and Technology', Cambridge Journal of Economics, 30 (4), pp. 587-611.

Kuznets, S. (1960) 'Population Change and Aggregate Output', in Demographic and Economic Change in Developing Countries, Special Conference Series No. 11, National Bureau Committee for Economic Research (Princeton: Princeton University Press).

Lall, S. (2000) 'The Technological Structure and Performance of Developing Country Manufactured Exports, 1985-98', Oxford Development Studies, 28 (3), pp. 337-69.

Laursen, S. and Metzler, L.A. (1950) 'Flexible Exchange Rates and the Theory of Employment'. Review of Economics and Statistics, 32 (4), pp. 281-299.

Love, I. and Zicchino, L. (2004) 'Financial Development and Dynamic Investment Behaviour: Evidence from Panel Vector Autoregression', World Bank Working Paper No. 2913, (Washington: DC).

Obstfeld, M. (1982) 'Aggregate Spending and the Terms of Trade: Is There a LaursenMetzler Effect?' Quarterly Journal of Economics, 97 (2), pp. 251-270.

Obstfeld, M. and Rogoff, K. (1995) 'The Intertemporal Approach to the Current Account', in G. M. Grossman, and K. Rogoff (eds), Handbook of International Economics, Vol. 3 (New York: Elsevier), pp. 1731-1799. 
Prebisch, R. (1950) 'The Economic Development of Latin America and Its Principal Problems', Economic Bulletin for Latin America No. 7 (United Nations: New York).

Sachs, J. (1981) 'The Current Account and Macroeconomic Adjustment in the 1970s'. Brookings Papers on Economic Activity, No. 1, pp. 201-282.

Santos-Paulino, A.U. (2007) 'Aid and Trade Sustainability under Liberalisation in Least Developed Countries', World Economy, 30 (6), pp. 972-998.

Santos-Paulino, A.U. and Thirlwall, A.P. (2004) 'The Impact of Trade Liberalisation on Export Growth, Import Growth, the Balance of Trade and the Balance of Payments of Developing Countries', Economic Journal, 114 (143), pp. F50-F72.

Servén, L. (2000) 'Macroeconomic Volatility in Latin America and the Caribbean: Causes and Remedies', in D. De Ferranti, G. Perry, I. Gill, and L. Servén (eds), Securing our Feature in a Global Economy (Washington, DC: World Bank).

Singer, H.W. (1950) 'The Distribution of Gains between Investing and Borrowing Countries', American Economic Review, 40 (May), pp. 473-85.

Svensson, L. and Razin, A. (1983) 'The Terms of Trade and the Current Account: The Harberger-Laursen-Metzler Effect', Journal of Political Economy, 1 (91), pp. 97-125.

Thirlwall, A.P. (1991) The Performance and Prospects of the Pacific Island Economies in the World Economy, (Hawaii: Pacific Island Development Program).

Thirlwall, A.P. (2003) Growth and Development with Special Reference to Developing Economies, (Basingstoke: Palgrave Macmillan).

UNCTAD (2005) UNCTAD Handbook of Statistics On-Line. Available at: www.unctad.org/TEMPLATES/Page.asp?intItemID=1890\&lang=1. 
Varella Mollick, A., Faria, J.R., Albuquerque, P.H. and León-ledesma, M.A. (2008) 'Can globalisation stop the decline in commodities' terms of trade?', Cambridge Journal of Economics, 32(5), pp. 683-701.

World Bank (2006) World Development Indicators 2006, World Bank (Washington: DC). 


\section{Appendix}

\section{Sources and description of the data}

Annual data for the three-variable vector auto-regression (VAR) panel are taken from the International Monetary Funds' International Financial Statistics (IFS), and the World Bank's World Development Indicators (WDI), generally for the period 1980-2005. However, the data ranges and availability vary between countries. The terms of trade (TOT) data is from the IFS, and UNCTAD's Handbook of Statistics, and is defined as the ratio of the export value index to import value index $(2000=100$, in percentage). The data for the current account and the real gross domestic product (GDP) are from the WDI, where real GDP $(y)$ values are in constant 2000US\$; the current account $(c a)$ is defined as the ratio of the current account balance to nominal GDP, in percentage. Data on disaggregate exports is from UNCTAD's COMTRADE (3-digits Standard Industry Classification Revision 2).

\section{Appendix Tables}

Table A1: The Sample of Small Island Developing Countries

\begin{tabular}{lll}
\hline $\begin{array}{l}\text { Africa and Indian } \\
\text { Ocean }\end{array}$ & \multicolumn{1}{c}{ Caribbean } & Asia and Pacific \\
\hline Cape Verde & Dominican Republic & Fiji \\
Comoros & Haiti & Papua New Guinea \\
Guinea Bissau & Jamaica & Samoa \\
Mauritius & Trinidad and Tobago & Singapore \\
Sao Tome \& Principe & & \\
Seychelles & & \\
\end{tabular}


Table A2: Export diversification and concentration in small island states

\begin{tabular}{|c|c|c|c|c|c|c|}
\hline & \multicolumn{3}{|c|}{1993} & \multicolumn{3}{|c|}{2003} \\
\hline & 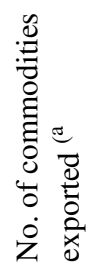 & 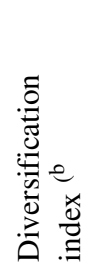 & 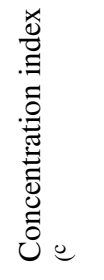 & 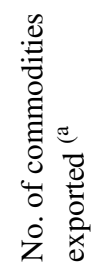 & 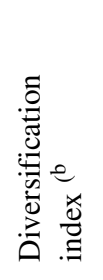 & 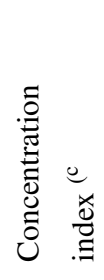 \\
\hline \multicolumn{7}{|l|}{ Caribbean } \\
\hline Dominican Republic & 100 & 0.50 & 0.17 & 114 & 0.62 & 0.21 \\
\hline Haiti & 28 & 0.44 & 0.26 & 49 & 0.49 & 0.47 \\
\hline Jamaica & 101 & 0.62 & 0.49 & 101 & 0.66 & 0.63 \\
\hline Trinidad and Tobago & 132 & 0.65 & 0.37 & 144 & 0.72 & 0.36 \\
\hline \multicolumn{7}{|l|}{ Pacific } \\
\hline Fiji & 92 & 0.59 & 0.32 & 96 & 0.51 & 0.27 \\
\hline Papa New Guinea & 71 & 0.64 & 0.41 & 80 & 0.65 & 0.37 \\
\hline Samoa & 7 & 0.48 & 0.83 & 24 & 0.48 & 0.68 \\
\hline \multicolumn{7}{|l|}{ Southern Africa } \\
\hline Comoros & 5 & 0.48 & 0.81 & 5 & 0.49 & 0.87 \\
\hline Mauritius & 108 & 0.65 & 0.33 & 157 & 0.70 & 0.28 \\
\hline Seychelles & 14 & 0.44 & 0.57 & 18 & 0.53 & 0.72 \\
\hline \multicolumn{7}{|l|}{ Western Africa } \\
\hline Cape Verde & 12 & 0.47 & 0.46 & 12 & 0.47 & 0.48 \\
\hline Guinea-Bissau & 16 & 0.45 & 0.49 & 15 & 0.51 & 0.76 \\
\hline $\begin{array}{l}\text { Sao Tome and } \\
\text { Principe }\end{array}$ & 16 & 0.44 & 0.62 & 8 & 0.51 & 0.93 \\
\hline \multicolumn{7}{|l|}{ South East Asia } \\
\hline Singapore & 226 & 0.46 & 0.19 & 222 & 0.47 & 0.25 \\
\hline Developing countries & 200 & 0.53 & 0.24 & 211 & 0.51 & 0.24 \\
\hline
\end{tabular}

Notes: (a Number of commodities (at SITC, Rev. 2, 3 digits group level) exported by a country. This includes only those products whose figures are greater than US $\$ 100,000$ or more than the 0.3 per cent of the country's total exports.

(b The diversification indicator predicts structural changes in a country's exports. Also, it evaluates if a change in the behaviour of exports is oriented towards more dynamic products demanded by the rest of the world, or by the main trade partners of a country. The diversification index ranges from 0 to 1 , and reveals the degree of differences between the structure of the country's trade and the world average. An index value closer to 1 indicates a bigger difference from the world average.

That is, $\quad A_{j}=\frac{1}{2} \sum_{k}\left|\frac{X_{j k}}{X_{j}}-\frac{X_{k}}{X}\right| \quad$ where $k$ is the product and $j$ is the country, and $X$ total exports.

(c Export concentration is measured by the Herfindahl-Hirschmann market concentration index. It ranges from 0 to 1 , where 1 represents maximum concentration. (UNCTAD, 2005). It is computed as:

$X H E R F_{j}=\sum_{i}\left[\frac{X_{i j}}{X_{i}}\right]^{2}$

Source: $\quad$ Author's own elaboration. 
Figure A1

Terms of trade and the current account balance, 1980-2005

Terms of trade $(2000=100)$ left scale, Current account as a share of GDP, right scale

Africa

Southern Africa
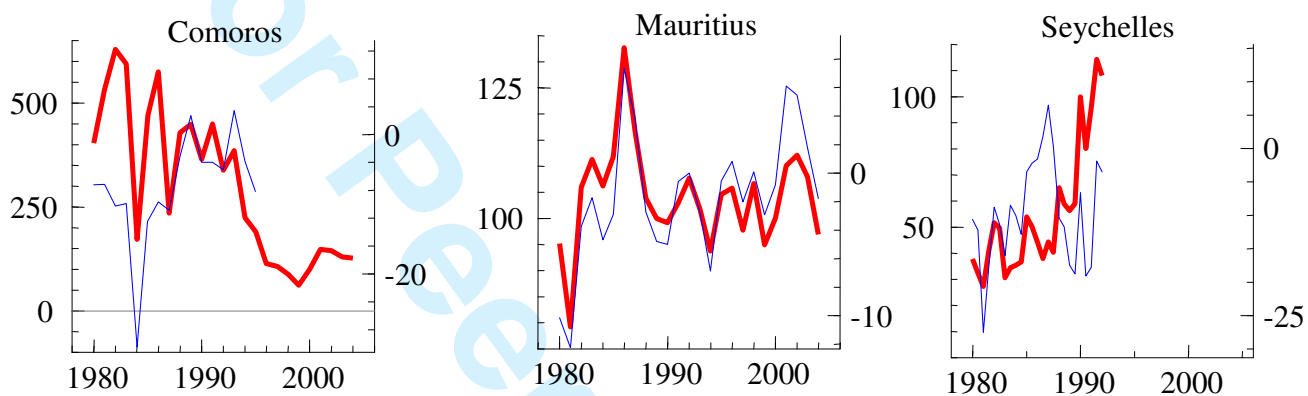

Western Africa
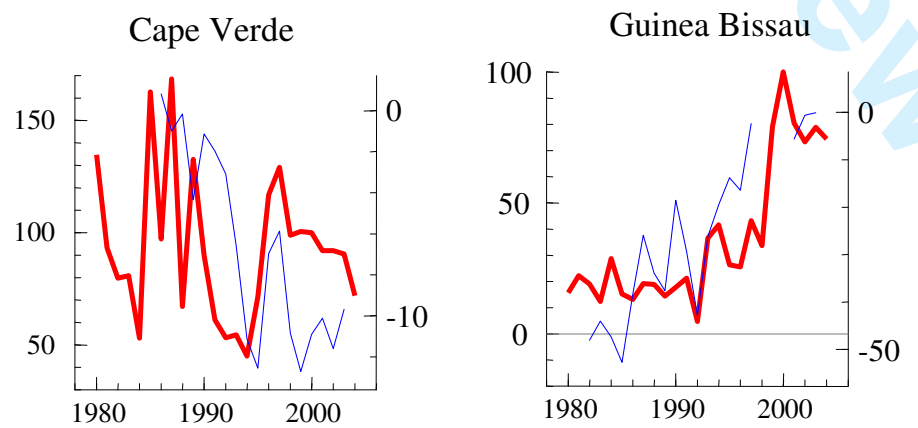

Sao Tome and Principe 


\section{Caribbean}

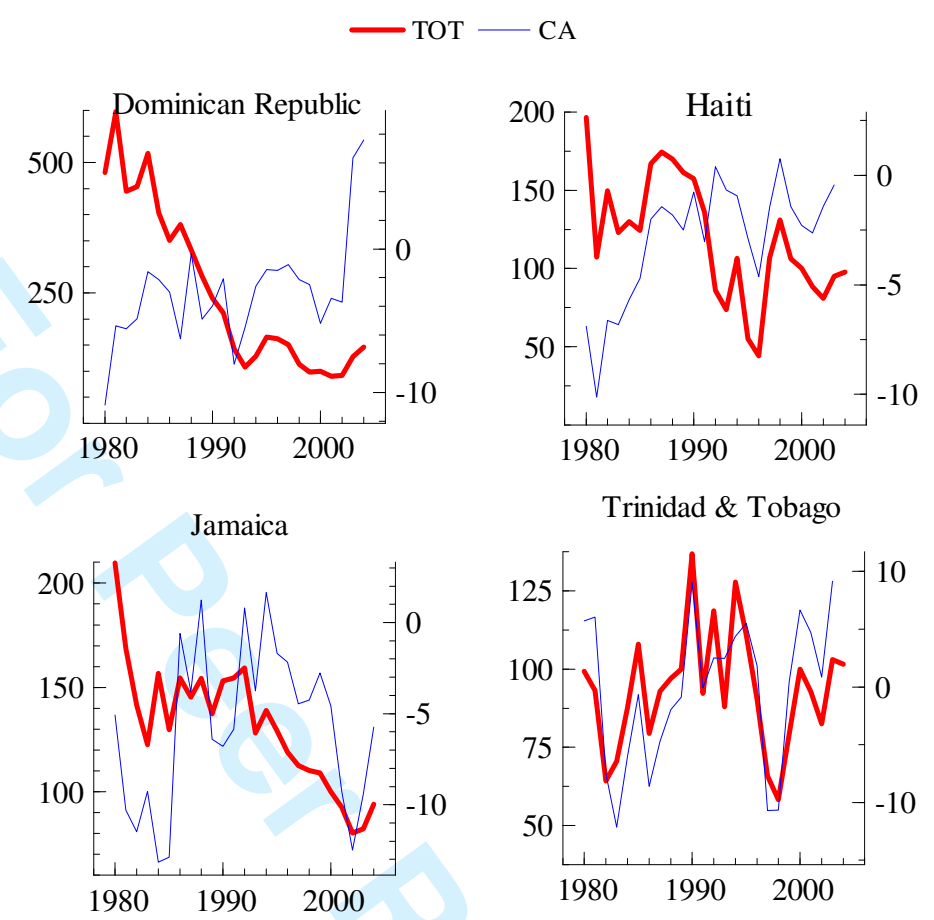

10 


\section{Pacific}
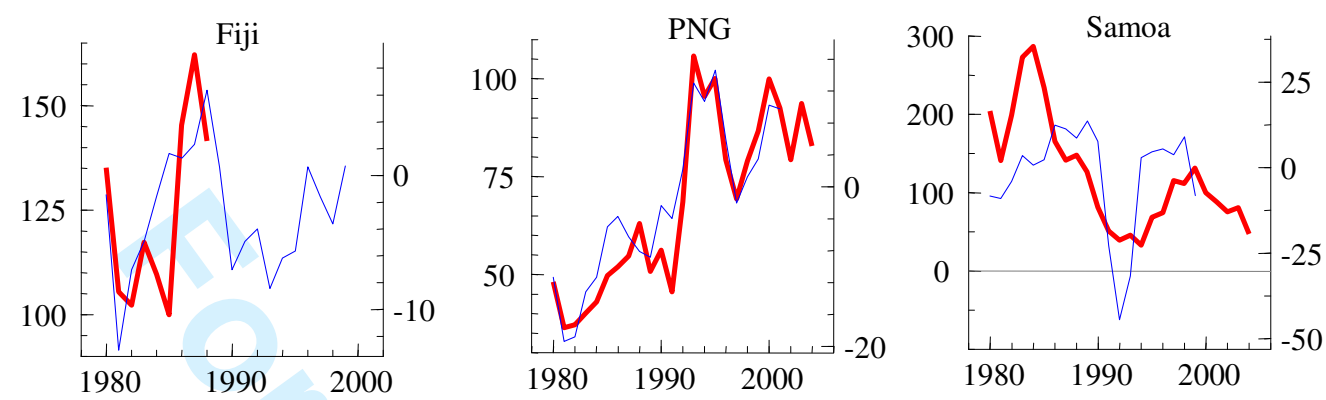

\section{South East Asia (Singapore)}

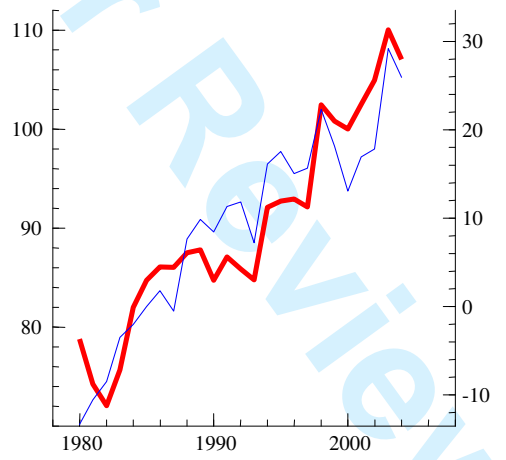


Figure A2

Terms of trade and real GDP growth, 1980-2005

Terms of trade $(2000=100)$ left scale, GDP growth right scale

\section{Africa}

\section{Southern Africa}

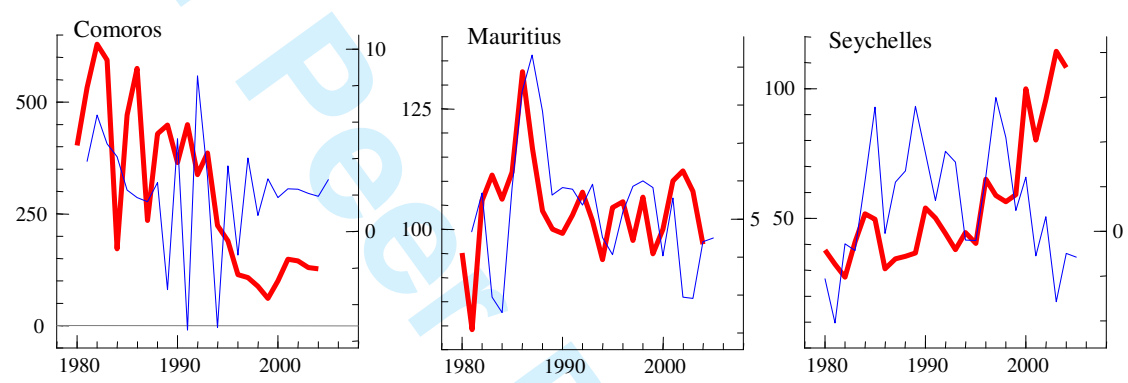

Western Africa
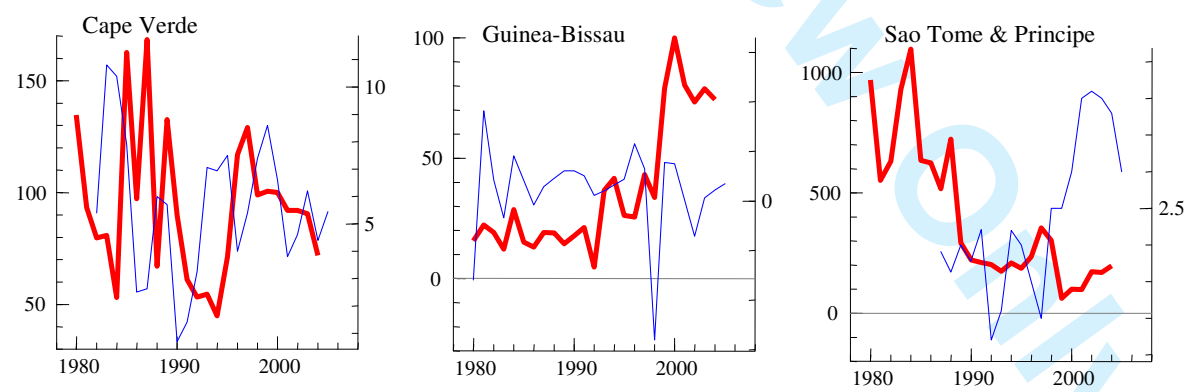


\section{Caribbean}
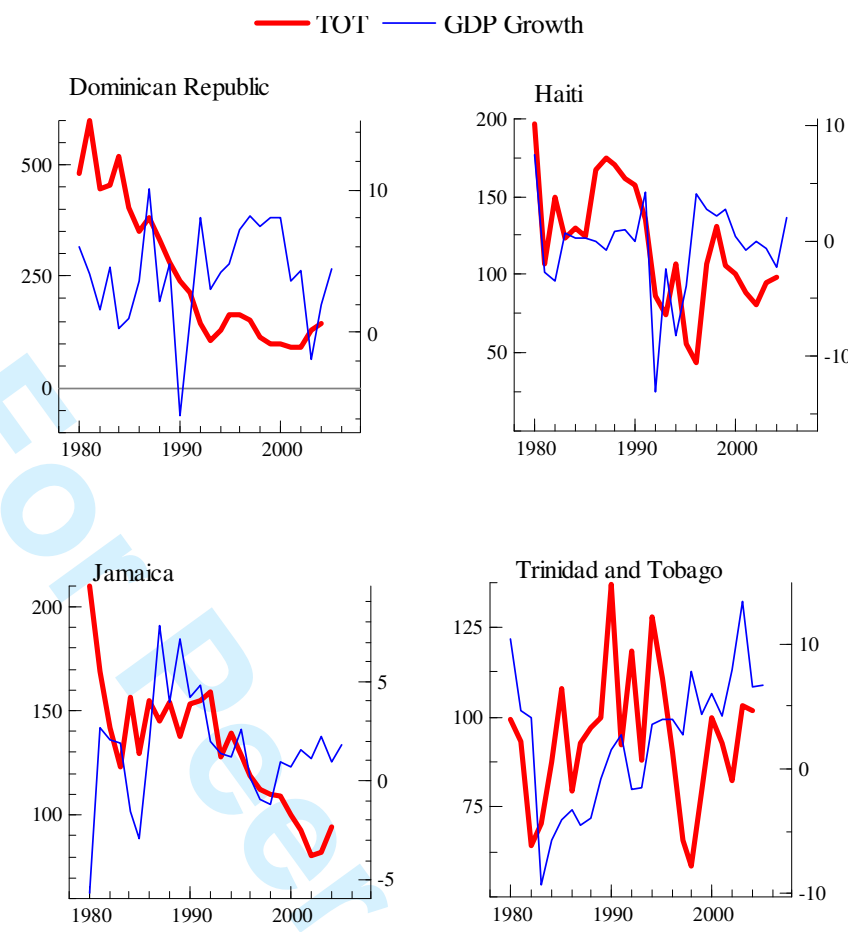

Pacific
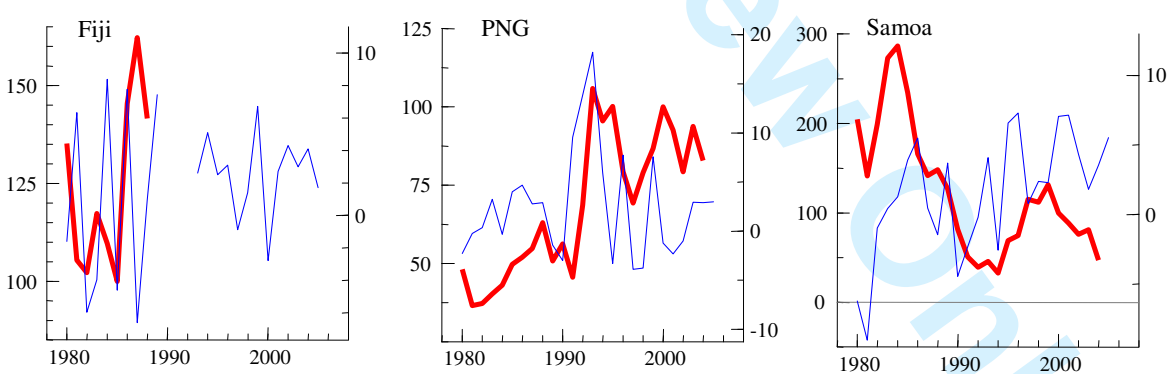
Southeast Asia (Singapore)

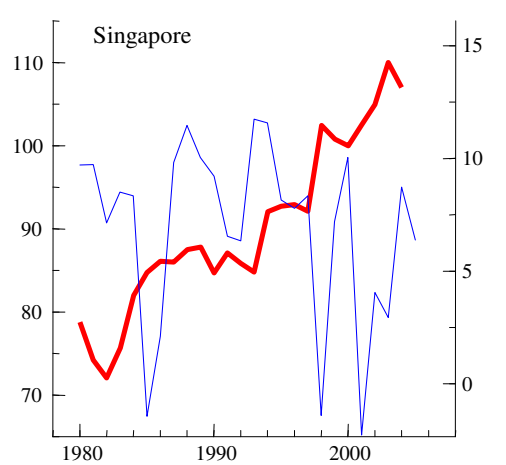

Source: Author's elaboration (see data appendix for sources and description).

Notes: In Figures A1 and A2, Fiji's TOT data is available until 1990. 
Table A3: Mean export composition (\%) by main sectors, 1980-94(a

\begin{tabular}{|c|c|c|c|c|c|c|c|c|}
\hline & $\begin{array}{l}\text { Primary } \\
\text { products }\end{array}$ & $\begin{array}{l}\text { Primary } \\
\text { products- } \\
\text { Minerals }\end{array}$ & $\begin{array}{l}\text { Resource-based } \\
\text { manufactures }\end{array}$ & $\begin{array}{l}\text { Resource-based } \\
\text { manufactures- } \\
\text { minerals (b }\end{array}$ & $\begin{array}{l}\text { Low-technology } \\
\text { manufactures }\end{array}$ & $\begin{array}{l}\text { Medium-technology } \\
\text { manufactures }\end{array}$ & Engineering & High technology \\
\hline Caribbean & 9.40 & 9.08 & 10.96 & 24.70 & 32.34 & 3.49 & 4.35 & 3.49 \\
\hline Dominican Rep. & 10.10 & 0.14 & 11.98 & 0.35 & 47.12 & 8.72 & 14.35 & 5.18 \\
\hline Haiti & 19.20 & 0.01 & 4.74 & 1.46 & 65.98 & 0.27 & 0.88 & 5.76 \\
\hline Jamaica & 7.31 & 0.36 & 15.21 & 60.44 & 10.92 & 1.61 & 1.09 & 2.27 \\
\hline Trinidad and Tobago & 1.00 & 35.82 & 11.92 & 36.57 & 5.34 & 3.36 & 1.10 & 0.77 \\
\hline Pacific & 28.66 & 0.96 & 33.90 & 19.07 & 4.57 & 0.89 & 1.28 & 1.92 \\
\hline Fiji & 4.46 & 0.09 & 54.55 & 13.48 & 11.69 & 1.41 & 1.16 & 3.09 \\
\hline Papua New Guinea & 21.25 & 2.63 & 14.04 & 43.20 & 0.24 & 0.27 & 1.29 & 1.52 \\
\hline Samoa & 60.28 & 0.17 & 33.11 & 0.52 & 1.80 & 0.98 & 1.41 & 1.14 \\
\hline Southern Africa & 11.17 & 0.04 & 28.43 & 27.82 & 23.92 & 0.40 & 2.27 & 3.82 \\
\hline \multicolumn{9}{|l|}{ Comoros } \\
\hline Mauritius & 1.97 & 0.02 & 41.13 & 2.27 & 47.23 & 0.48 & 3.26 & 0.60 \\
\hline Seychelles & 20.36 & 0.06 & 15.73 & 53.37 & 0.60 & 0.32 & 1.28 & 7.04 \\
\hline Western Africa & 33.45 & 5.12 & 11.36 & 0.29 & 1.54 & 1.09 & 0.22 & 0.10 \\
\hline Cape Verde & 33.45 & 5.12 & 11.36 & 0.29 & 1.54 & 1.09 & 0.22 & 0.10 \\
\hline \multicolumn{9}{|l|}{ Guinea-Bissau } \\
\hline \multicolumn{9}{|l|}{ Sao Tome and Principe } \\
\hline South East Asia & 6.04 & 1.76 & 7.25 & 20.86 & 8.08 & 4.74 & 15.48 & 28.38 \\
\hline Singapore & 6.04 & 1.76 & 7.25 & 20.86 & 8.08 & 4.74 & 15.48 & 28.38 \\
\hline
\end{tabular}

Notes: (a Arithmetic mean. Data availability vary by country; (b Mineral refers to precious metals, minerals, and sub-products (including oil). Source: Author's own elaboration. 
Table A4: Mean export composition (\%) by main sectors, $1995-2005^{(a}$

\begin{tabular}{|c|c|c|c|c|c|c|c|c|}
\hline & $\begin{array}{l}\text { Primary } \\
\text { products }\end{array}$ & $\begin{array}{l}\text { Primary } \\
\text { products- } \\
\text { Minerals }\end{array}$ & $\begin{array}{l}\text { Resource-based } \\
\text { manufactures }\end{array}$ & $\begin{array}{l}\text { Resource-based } \\
\text { manufactures- } \\
\text { minerals (b }\end{array}$ & $\begin{array}{l}\text { Low-technology } \\
\text { manufactures }\end{array}$ & $\begin{array}{l}\text { Medium-technology } \\
\text { manufactures }\end{array}$ & Engineering & High technology \\
\hline Caribbean & 11.37 & 8.79 & 13.73 & 28.69 & 28.18 & 3.93 & 1.47 & 1.54 \\
\hline \multicolumn{9}{|l|}{ Dominican Rep. } \\
\hline Haiti & 23.75 & 0.01 & 8.60 & 0.04 & 63.31 & 0.08 & 0.24 & 2.56 \\
\hline Jamaica & 9.06 & 0.33 & 15.96 & 55.62 & 13.09 & 2.57 & 0.88 & 1.30 \\
\hline Trinidad and Tobago & 1.29 & 26.03 & 16.64 & 30.40 & 8.14 & 9.13 & 3.27 & 0.77 \\
\hline Pacific & 14.21 & 8.03 & 18.23 & 15.66 & 12.83 & 0.53 & 23.17 & 1.13 \\
\hline Fiji & 13.77 & 0.26 & 34.73 & 6.88 & 32.23 & 1.02 & 0.70 & 1.21 \\
\hline Papua New Guinea & 10.85 & 23.77 & 12.93 & 39.65 & 0.31 & 0.16 & 1.24 & 1.69 \\
\hline Samoa & 18.01 & 0.05 & 7.03 & 0.45 & 5.93 & 0.41 & 67.58 & 0.48 \\
\hline Southern Africa & 27.42 & 0.14 & 32.52 & 10.63 & 21.11 & 1.09 & 1.82 & 3.82 \\
\hline Comoros & 73.59 & 0.30 & 18.59 & 0.00 & 0.38 & 1.92 & 1.92 & 0.60 \\
\hline Mauritius & 2.20 & 0.05 & 24.58 & 2.62 & 62.44 & 0.93 & 2.83 & 2.78 \\
\hline Seychelles & 6.47 & 0.05 & 54.40 & 29.26 & 0.50 & 0.43 & 0.70 & 8.08 \\
\hline Western Africa & 62.08 & 0.04 & 2.03 & 10.73 & 16.06 & 6.34 & 4.01 & 1.46 \\
\hline Cape Verde & 4.84 & 0.06 & 2.10 & 27.62 & 47.26 & 15.28 & 6.87 & 4.16 \\
\hline Guinea-Bissau & 86.38 & 0.05 & 1.83 & 4.56 & 0.50 & 2.72 & 3.88 & 0.07 \\
\hline Sao Tome and Principe & 95.01 & 0.00 & 2.15 & 0.00 & 0.41 & 1.02 & 1.28 & 0.16 \\
\hline South East Asia & 1.21 & 1.03 & 5.16 & 8.79 & 6.25 & 5.24 & 11.99 & 54.77 \\
\hline Singapore & 1.21 & 1.03 & 5.16 & 8.79 & 6.25 & 5.24 & 11.99 & 54.77 \\
\hline
\end{tabular}

Notes: See notes to Appendix Table A3. Source: Author's own elaboration. 